\title{
ANALISIS SWOT PADA HOTEL BANYUALIT SINGARAJA
}

\author{
Santi Melasari ${ }^{1}$, I Nyoman Sujana ${ }^{2}$, Kadek Rai Suwena ${ }^{3}$ \\ Program Studi Pendidikan Ekonomi, Fakultas Ekonomi \\ Universitas Pendidikan Ganesha \\ Singaraja, Indonesia \\ e-mail: santimelasari@gmail.com¹, nyoman.sujana@undiksha.ac.id², \\ kadeksuwena@yahoo.co.id ${ }^{3}$
}

\begin{abstract}
Abstrak
Penelitian ini bertujuan untuk mengetahui kekuatan, kelemahan, peluang, dan ancaman yang dihadapi, serta strategi yang tepat untuk diterapkan pada Hotel Banyualit Singaraja. Data dikumpulkan dengan metode kuesioner dan wawancara. Data dianalisis dengan menggunakan metode analisis deskriptif. Dari hasil penelitian ini, kekuatan yang dimiliki meliputi fasilitas hotel cukup lengkap dan memadai, harga yang kompetitif, lokasi cukup strategis, kebersihan dan kenyamanan yang terjaga, karyawan yang ramah, dan adanya tempat bermain untuk anak-anak; kelemahan yang dimiliki meliputi promosi yang belum efektif dan berkesinambungan, jumlah kamar yang sedikit kurang bisa memenuhi permintaan tamu, fasilitas gym yang belum tersedia, sistem perekrutan karyawan masih bersifat kekeluargaan, dan Hotel Banyualit termasuk hotel tua sehingga terkadang ada keluhan dan saran dari para tamu yang menginap di sana; peluang yang dimiliki meliputi memiliki pelanggan tetap, kerja sama yang baik dengan supplier, kondisi alam yang menjadi daya tarik para wisatawan untuk datang ke Buleleng, pendapatan per kapita wisatawan yang tinggi akan menjadi peluang wisawatan untuk melakukan perjalanan lebih lama sehingga lama menginap di hotel juga lebih panjang, pangsa pasar lebih dominan menginap di hotel berasal dari wisatawan mancanegara, dan adanya permintaan terhadap produk-produk restoran hotel dari orang luar yang bukan tamu; ancaman yang dihadapi meliputi terdapat banyak hotel yang sejenis, perkembangan teknologi yang pesat, banyaknya pendatang baru yang masuk ke industri penginapan sejenis hotel, dan meningkatnya jumlah fasilitas dan kualitas pelayanan yang dimiliki hotel pesaing; dan strategi yang tepat untuk diterapkan adalah growth oriented strategy.
\end{abstract}

Kata kunci: SWOT, IFAS, EFAS

\begin{abstract}
This study aims to determine the strengths, weaknesses, opportunities, and threats faced, and the right strategies to be applied to the Singaraja Banyualit Hotel. Data was collected by questionnaire and interview methods. Data were analyzed using descriptive analysis method. From the results of this study, the strengths possessed include fairly complete and adequate hotel facilities, competitive prices, quite strategic locations, maintained cleanliness and comfort, friendly employees, and a playground for children; weaknesses include promotions that have not been effective and sustainable, the number of rooms that are less able to meet guest requests, gym facilities that are not yet available, employee recruitment systems are still family, and Hotel Banyualit is an old hotel so sometimes there are complaints and suggestions from guests stay there; opportunities include having regular customers, good cooperation with suppliers, natural conditions that attract tourists to come to Buleleng, high tourist per capita income will be an opportunity for tourists to travel longer so the length of stay in hotels is also more long, more dominant market share staying at hotels comes from foreign tourists, and there is a demand for hotel restaurant products from outsiders who are not guests; the threats faced include many similar hotels, rapid technological developments, the large number of newcomers entering the hotel-type lodging industry, and the increasing number of facilities and service quality owned by competing hotels; and the right strategy to implement is growth oriented strategy.
\end{abstract}

Keywords: SWOT, IFAS, EFAS 


\section{PENDAHULUAN}

Pengembangan

ditentukan dengan kemampuan membangun strategi. Karena strategi memaksa perusahaan untuk memandang masa depan dan berusaha membentuk masa depannya secara proaktif. "Strategi membantu memberikan kesadaran tentang arah yang dituju perusahaan, menjaga kesinambungannya, serta memudahkan pendelegasian dan proses terjadinya kepemimpinan yang efektif" (Susanto, 2014:11). Setiap perusahaan harus menggunakan strategi untuk mengembangkan usahanya. Tidak hanya perusahaan besar saja yang mempunyai manajemen strategis, perusahaan kecilpun sebaiknya dikelola dengan menggunakan manajemen strategis. "Manajemen strategis merupakan sekumpulan keputusan dan tindakan yang dirancang untuk mencapai sasaran perusahaan" (Suyanto, 2007:10). Dengan demikian manajemen strategis melibatkan pengambilan keputusan berjangka panjang dan rumit serta berorientasi ke masa depan.

Dalam dunia usaha diberbagai sektor selalu menghadapi persaingan antar produsen, oleh karena itu setiap produsen harus mampu bersaing dengan produsen lainnya apabila ingin tetap survive (langgeng) dalam dunia usahanya. Di samping itu perusahaan harus mampu memenuhi kepuasan konsumen, sehingga kualitas produk dan harga harus dijadikan prioritas utama. Hal ini bertujuan untuk menjaga kestabilan usaha yang dilakukan dan dalam rangka peningkatan keuntungan usaha serta menarik kepercayaan masyarakat. Bagaimanapun bentuk dan baiknya kualitas produk yang dihasilkan, tidak akan berkembang sesuai dengan target yang diinginkan tanpa adanya pemasaran. Oleh karena itu, peran pemasaran akan menentukan berjalan atau tidaknya usaha yang dilakukan. Sehingga dengan dua aspek (pemasaran dan produksi) yang dilakukan secara cermat akan berpengaruh terhadap keuntungan yang diperoleh.

Dewasa ini, persaingan dalam industri jasa semakin ketat. Hal ini tidak lepas dari banyaknya pemain atau perusahaan baik besar maupun kecil yang berkecimpung di dalam industri tersebut. Peran industri jasa sangat penting untuk pertumbuhan ekonomi Indonesia yang diukur berdasarkan kenaikan Produk Domestik Bruto (PDB). Sektor jasa merupakan sektor penyumbang PDB terbesar setelah sektor manufaktur di Indonesia (Mustami, 2016).

Industri hotel dan restoran nasional saat itu diprediksi tumbuh sekitar $5 \%$ pada tahun 2017. Sekretaris Jenderal Persatuan Hotel dan Restoran Indonesia (PHRI) Kosmian Pudjiadi mengatakan, pertumbuhan itu didorong oleh makin banyaknya wisatawan mancanegara dan domestik yang menggunakan jasa hotel dan restoran sebagai pelengkap perjalanan mereka (Nurcahya, 2017).

Hotel Banyualit adalah salah satu hotel bintang tiga yang menggunakan konsep ramah lingkungan dengan menggunakan tool yang tidak mencemari lingkungan (user friendly). Tujuan Hotel Banyualit adalah menyediakan dan memberikan para customer harapan serta keinginan mereka dengan pelayanan terbaik.

Tingkat hunian kamar Hotel Banyualit dari bulan Oktober 2017 hingga Maret 2018 bergerak secara fluktuatif dengan persentase rata-rata hanya sebesar $67,17 \%$. Tingkat hunian ini harus lebih ditingkatkan pada angka di atas $90 \%$ agar dapat meningkatkan keuntungan dan memperluas pangsa pasar diantara para pesaing yang telah mapan seperti Hotel Aneka Lovina dan Hotel Aditya (Data Primer Hotel Banyualit diolah Tahun 2018). Pesaing-pesaing lain bahkan memiliki fasilitas seperti jumlah kamar yang jauh lebih banyak dari Hotel Banyualit sebagai sumber pendapatan mereka. Berkaitan dengan hal tersebut, perencanaan strategi merupakan unsur penting yang perlu dibangun oleh Hotel Banyualit dalam menghadapi persaingan yang ketat agar mampu memaksimalkan tingkat hunian, menguasai pasar, dan bersaing dengan sukses, sehingga dapat memberikan keuntungan bagi perusahaan.

Menurut Tunggal (2001: 74-75), "SWOT adalah akronim untuk kekuatan 
(strength) dan kelemahan (weakness) internal suatu perusahaan dan peluang (opportunities) dan ancaman (threats) lingkungan yang dihadapi perusahaan". Analisa SWOT merupakan identifikasi yang sistematis dari faktor-faktor ini dan strategi yang menggambarkan pedoman yang terkait antara mereka.

Menurut Daft (2003: 314), "analisis SWOT merupakan analisis terhadap empat elemen yang terdiri dari, yang pertama kekuatan (strength), merupakan karakteristik positif internal yang dapat dieksploitasi organisasi untuk meraih sasaran kinerja strategi. Kedua kelemahan (weakness), merupakan karakteristik internal yang dapat menghalangi atau melemahkan kinerja organisasi. Ketiga peluang (opportunities), merupakan karakteristik dari lingkungan eksternal yang memiliki potensi untuk membantu organisasi meraih atau melampaui sasaran strategi. Dan yang keempat ancaman (treath), merupakan karakteristik dari lingkungan eksternal yang dapat mencegah organisasi meraih sasaran strategi yang telah ditetapkan".

Tujuan dari analisis SWOT adalah sebagai berikut, yakni yang pertama memanfaatkan keuntungan dari kekuatan yang dimiliki dan peluang yang ada. Dan yang kedua meminimalisasi kelemahan dan mengeliminasi ancaman. Yang ketiga, analisis SWOT sangat berguna untuk mengenali situasi, lingkungan, dan kondisi saat ini untuk keperluan pengambilan keputusan-keputusan, menentukan langkah-langkah yang sebaiknya dilakukan oleh perusahaan terhadap kelangsungan hidup aktivitas bisnisnya. Analisis SWOT memberikan alur pikir yang baik untuk keperluan peninjauan strategi, posisi, dan arah perusahaan pengambilan posisi bisnis dalam industri, mengevaluasi kompetitor, pengambilan kebijakan dalam perencanaan strategi marketing atau bisnis, membuat laporan penelitian, brainstorming saat meeting, atau kebutuhan lainnya.

Terdapat dua faktor pokok yang mempengaruhi keempat komponen dasar pada analisis SWOT diantaranya yaitu sebagai berikut, yakni yang pertama lingkungan internal adalah lingkungan yang dapat dipengaruhi oleh perusahaan
(Yogi, dkk., 2007: 40). Lingkungan internal itu terdiri dari variabel kekuatan dan kelemahan yang ada di dalam organisasi. Variabel-variabel tersebut membentuk suasana dimana pekerjaan dilakukan. Menurut Asri (2001: 30), "marketing mix adalah variabel-variabel pemasaran (product, price, placement, dan promotion), yang akan dikombinasikan oleh perusahaan untuk memperoleh hasil yang maksimal". Yang pertama produk atau product, dari elemen-elemen marketing mix yang ada maka produk merupakan elemen yang paling penting, sebab dengan produk perusahaan dapat memenuhi kebutuhan dan keinginan konsumen. Jika kebutuhan tentang produk sangat baik yaitu memenuhi kebutuhan dan keinginan konsumen, maka perusahaan tidak terlalu dituntut untuk membuat keputusan yang terlalu baik dalam 3P lainnya. Sebaliknya, jika produknya kurang memenuhi kebutuhan dan keinginan konsumen, walaupun harganya miring, distribusinya luas, dan promosinya gencar, perusahaan kemungkinan besar akan mengalami kegagalan. Kedua, harga atau price dari penetapan harga jual bagi suatu produk sangatlah penting. Kesalahan pada penetapan harga akan berakibat fatal pada segi keuangan dan akan berpengaruh pada kuantitas perusahaan. Ketiga, distribusi (channel of distribution) atau place, setelah produk dikembangkan dan harga telah ditetapkan, maka keputusan penting lainnya adalah menggunakan saluran distribusi, yang juga mendapat perhatian dalam rangka keberhasilan strategi pemasaran. Salah satu tujuan dari place adalah agar konsumen dapat dengan mudah memperoleh dan membeli produk atau jasa perusahaan. Bentuk-bentuk saluran distribusi yang dipergunakan memasarkan produknya berbeda-beda, tergantung pada jenis produk dan kelompok konsumen yang menjadi sasarannya.

Menurut Kotler dan Susanto (2000:

41), "distribusi adalah berbagai kegiatan yang membuat produk dapat terjangkau oleh konsumen sasaran". Menurut Irawan, dkk., (2001: 135), mendefinisikan "saluran distribusi sebagai himpunan perusahaan dan perorangan yang mengambil alih hak 
atau membantu dalam pengalihan hak atas barang atau jasa selama berpindah dari produsen ke konsumen". Yang pertama promosi atau promotion. Definisi promosi menurut Kotler dan Susanto (2000: 41) adalah "berbagai kegiatan yang dilakukan perusahaan untuk menonjolkan keistimewaan produknya dan membujuk konsumen sasaran agar membeli produk tersebut". Menurut Irawan, dkk. (2001: 163), "kegiatan promosi adalah komunikasi”.

Kegiatan promosi yang dilakukan perusahaan sangat menunjang ketiga elemen marketing mix di atas. Istilah promosi meliputi berbagai kegiatan yang kesemuanya termasuk dalam "marketing communication". Yang pertama, lingkungan eksternal, "lingkungan eksternal adalah lingkungan yang tidak dapat dipengaruhi oleh perusahaan" (Yogi, dkk. 2007: 32). Lingkungan eksternal terdiri dari variabel peluang dan ancaman yang berada di luar organisasi.

Lingkungan eksternal perusahaan dibagi dalam tiga wilayah utama, yaitu sebagai berikut, yang pertama, lingkungan umum, "lingkungan umum adalah sekumpulan elemen-elemen dalam masyarakat yang lebih luas yang mempengaruhi suatu industri dan perusahaan-perusahaan yang ada di dalamnya" (Hitt, 2001: 50). Kedua, lingkungan industri, ingkungan industri adalah serangkaian faktor-faktor ancaman dari pelaku bisnis baru, supplier, pembeli, produk pengganti, dan intensitas persaingan di antara para pesaing yang secara langsung mempengaruhi perusahaan. Secara keseluruhan, interaksi di antara lima faktor ini menempatkan suatu posisi dalam suatu industri, dimana perusahaan dapat secara menguntungkan mempengaruhi faktorfaktor itu, atau di mana perusahaan itu dapat dengan sukses mempertahankan diri dari pengaruh-pengaruh mereka. "Semakin besar kapasitas perusahaan untuk lebih mempengaruhi lingkungan industri, semakin besar kemungkinan perusahaan untuk menghasilkan laba di atas rata-rata" (Hitt, 2001: 50-52). Ketiga, lingkungan pesaing, "lingkungan pesaing memusatkan perhatiannya pada setiap perusahaan yang bersaing secara langsung dengan sebuah perusahaan. Analisis pesaing dilakukan dengan penuh semangat oleh perusahaan-perusahaan yang bersaing dalam sebuah industri dengan hanya sedikit perusahaan yang memiliki kapabilitas yang relatif seimbang" (Hitt, 2001: 83).

Berdasarkan pengamatan yang telah dilakukan dan digabungkan dengan teori-teori dan penelitian terdahulu yang berkaitan, maka pada penelitian ini penulis akan meneliti mengenai "Analisis SWOT pada Hotel Banyualit Singaraja".

\section{METODE}

Peneliti dalam melaksanakan penelitian ini menggunakan rancangan penelitian deskriptif. Rancangan penelitian deskriptif dipilih karena mampu menggambarkan analisis SWOT pada Hotel Banyualit Singaraja. Penelitian deskriptif dengan pendekatan kuantitatif digunakan untuk memperoleh skor pada masing-masing variabel, yaitu variabel kekuatan, variabel kelemahan, variabel peluang, dan variabel ancaman. Penelitian deskriptif dengan pendekatan kualitatif digunakan untuk menggambarkan strategi yang tepat untuk diterapkan pada Hotel Banyualit Singaraja.

Penelitian ini dilakukan untuk mengetahui lingkungan internal dan lingkungan eksternal, melalui lingkungan internal dan lingkungan eksternal akan diketahui strategi yang tepat untuk diterapkan pada Hotel Banyualit Singaraja. Lingkungan internal terdapat variabel kekuatan dan kelemahan, lingkungan eksternal terdapat variabel peluang dan ancaman. Adapun indikator pada lingkungan internal dalam penelitian ini yaitu produk, harga, sumber daya manusia, dan sumber daya fisik. Indikator pada lingkungan eksternal dalam penelitian ini yaitu pesaing, teknologi, pembeli, dan supplier.

Lokasi penelitian adalah Hotel Banyualit yang beralamat di Jalan Laviana, Kalibukbuk, Lovina. Populasi yang digunakan dalam penelitian ini adalah customer atau tamu yang menginap di Hotel Banyualit periode Juli s/d September 2018, yaitu sebanyak 215 orang yang terdiri dari wisatawan 
domestik, wisatawan mancanegara, dan pegawai pemerintah/ swasta.

Teknik sampel yang digunakan dalam penelitian ini adalah teknik aksidental. "Pengambilan sampel dengan teknik aksidental atau accidental sampling ini adalah teknik penentuan sampel berdasarkan kebetulan atau siapa saja yang bertemu dengan peneliti dapat dijadikan sebagai sampel, dan bila orang yang ditemui tersebut dipandang cocok sebagai sumber data" (Sugiyono, 2001: 96).

Penelitian ini menggunakan jenis data kualitatif dan kuantitatif berupa data yang diambil dari beberapa pihak internal Hotel Banyualit, untuk kemudian ditelaah dan dianalisis serta difokuskan pada bidang manajemen strategi. Sumber data yang digunakan dalam penelitian ini adalah data primer dan data sekunder. Adapun metode yang digunakan dalam mengumpulkan data adalah metode kuesioner dan wawancara.

Instrumen penelitian ini berupa kuisioner yang disebarkan kepada responden, yaitu tamu/ pengunjung Hotel Banyualit Singaraja. Kuisioner yang dirancang dengan menggunakan Skala Likert, dimana skala ini merupakan "skala yang digunakan untuk memperlihatkan tanggapan responden terhadap karakteristik suatu produk melalui daftar pertanyaan yang diperoleh dari masingmasing item dari dalam setiap variabel maka disarankan alternatif pilihannya lima saja" (Durianto, 2001:41).

Teknik analisis data yang digunakan dalam penelitian ini adalah analisis deskriptif dengan pendekatan kuantitatif dan kualitatif. Analisis deskriptif kuantitatif digunakan untuk memperoleh skor pada masing-masing variabel, sedangkan analisis deskriptif dengan pendekatan kualitatif digunakan untuk menggambarkan secara jelas mengenai strategi yang tepat untuk diterapkan pada Hotel Banyualit Singaraja.

\section{HASIL DAN PEMBAHASAN Hasil Penelitian}

Berdasarkan hasil penelitian melalui observasi dan wawancara yang dilakukan pada narasumber, peneliti memperoleh data bahwa kekuatan (strength) yang dimiliki oleh Hotel Banyualit Singaraja adalah fasilitas hotel cukup lengkap dan memadai, harga yang kompetitif, lokasi cukup strategis, kebersihan dan kenyamanan, karyawan yang ramah, dan adanya tempat bermain untuk anak-anak.

Kelemahan (weakness) yang dimiliki oleh Hotel Banyualit Singaraja adalah promosi yang belum efektif dan berkesinambungan, jumlah kamar yang sedikit kurang bisa memenuhi permintaan tamu, fasilitas gym yang belum tersedia, sistem perekrutan karyawan masih bersifat kekeluargaan, dan hotel Banyualit termasuk hotel tua, sehingga terkadang ada keluhan dan saran dari para tamu yang menginap di sana.

Peluang (opportunities) yang dimiliki oleh Hotel Banyualit Singaraja adalah memiliki pelanggan tetap, kerja sama yang baik dengan supplier, kondisi alam yang menjadi daya tarik para wisatawan untuk datang ke Buleleng, pendapatan per kapita wisatawan yang tinggi akan menjadi peluang wisawatan untuk melakukan perjalanan lebih lama sehingga lama menginap di hotel juga lebih panjang, pangsa pasar yang lebih dominan menginap di hotel berasal dari wisatawan mancanegara, dan adanya permintaan terhadap produk-produk restoran hotel dari orang luar yang bukan tamu.

Ancaman (treath) yang dimiliki oleh Hotel Banyualit adalah terdapat banyak hotel yang sejenis di daerah Lovina, perkembangan teknologi yang pesat, banyaknya pendatang baru yang masuk ke industri penginapan sejenis hotel (home stay, guest house, hostel, losmen, dan sebagainya), dan meningkatnya jumlah fasilitas dan kualitas pelayanan yang dimiliki hotel pesaing.

Dari hasil pengumpulan data yang dilakukan pada Hotel Banyualit Singaraja, data yang diperoleh dimasukkan dan diolah ke dalam bentuk tabel analisis faktor strategis internal/ IFAS dan analisis faktor strategis eksternal/ EFAS untuk memperoleh total skor pada masingmasing faktor, yaitu kekuatan (strength), kelemahan (weakness), peluang (opportunities), dan ancaman (treath). 
p-ISSN : 2599-1418

e-ISSN : 2599-1426
Jurnal Pendidikan Ekonomi Undiksha

Volume 10 No. 2 Tahun 2018

Total skor yang diperoleh tersebut diperlukan untuk menggambarkan matriks

SWOT. Dapat dilihat pada tabel 1.

Tabel 1. Faktor-faktor Strategis Internal (Internal Strategic Factors Analysis Summary/ IFAS) Kekuatan/ Strenght

\begin{tabular}{l|c|c|c}
\hline $\begin{array}{c}\text { Faktor-faktor Strategis Internal Kekuatan/ } \\
\text { Strenght }\end{array}$ & Bobot & Rating & $\begin{array}{c}\text { Skor/ } \\
\text { Nilai }\end{array}$ \\
\hline 1. Fasiltas hotel cukup lengkap dan memadai & 0,2 & 4 & 0,8 \\
2. Harga yang kompetitif & 0,2 & 4 & 0,8 \\
3. Lokasi cukup strategis & 0,2 & 4 & 0,8 \\
4. Kebersihan dan kenyamanan & 0,2 & 2 & 0,4 \\
5. Karyawan yang ramah & 0,1 & 2 & 0,2 \\
6. Adanya tempat bermain untuk anak-anak & 0,1 & 2 & 0,2 \\
\hline \multicolumn{1}{c|}{ Total } & 1,0 & 18 & 3,2 \\
\hline
\end{tabular}

Tabel 2. Faktor-faktor Strategis Internal (Internal Strategic Factors Analysis Summary/ IFAS) Kelemahan/ Weakness

\begin{tabular}{|c|c|c|c|c|}
\hline & $\begin{array}{l}\text { Faktor-faktor Strategis Internal Kelemahan/ } \\
\text { Weakness }\end{array}$ & Bobot & Rating & $\begin{array}{l}\text { Skor/ } \\
\text { Nilai }\end{array}$ \\
\hline 1. & $\begin{array}{llll}\begin{array}{l}\text { Promosi yang } \\
\text { berkesinambungan }\end{array} & \text { belum } & \text { efektif } & \text { dan }\end{array}$ & 0,2 & 3 & 0,6 \\
\hline 2. & $\begin{array}{l}\text { Jumlah kamar yang sedikit kurang bisa } \\
\text { memenuhi permintaan tamu }\end{array}$ & 0,2 & 3 & 0,6 \\
\hline 3. & Fasilitas gym yang belum tersedia & 0,2 & 2 & 0,4 \\
\hline & $\begin{array}{l}\text { Sistem perekrutan karyawan masih bersifat } \\
\text { kekeluargaan }\end{array}$ & 0,2 & 2 & 0,4 \\
\hline 5. & $\begin{array}{l}\text { Hotel Banyualit termasuk hotel tua, sehingga } \\
\text { terkadang ada keluhan dan saran dari para tamu } \\
\text { yang menginap di sana. }\end{array}$ & 0,2 & 2 & 0,4 \\
\hline & Total & 1,0 & 12 & 2,4 \\
\hline
\end{tabular}

Tabel 3. Faktor-faktor Strategis Eksternal (External Strategic Factors Analysis Summary/ EFAS) Peluang/ Opportunities

\begin{tabular}{l|c|c|c}
\hline Faktor-faktor Strategis Eksternal Peluang/ & Bobot & Rating & Skor/ Nilai \\
\hline $\begin{array}{l}\text { Opportunities } \\
\text { 1. Memiliki pelanggan tetap }\end{array}$ & 0,3 & 4 & 1,2 \\
$\begin{array}{l}\text { 2. Kerja sama yang baik dengan supplier } \\
\text { 3. Kondisi alam yang menjadi daya tarik para } \\
\text { wisatawan untuk datang ke Buleleng }\end{array}$ & 0,2 & 3 & 0,6 \\
$\begin{array}{l}\text { 4. Pendapatan per kapita wisatawan yang } \\
\text { tinggi akan menjadi peluang wisawatan } \\
\text { untuk melakukan perjalanan lebih lama }\end{array}$ & 0,1 & 3 & 0,8 \\
$\begin{array}{l}\text { sehingga lama menginap di hotel juga lebih } \\
\text { panjang. }\end{array}$ & & 3 & 0,3 \\
$\begin{array}{l}\text { 5angsa pasar yang lebih dominan } \\
\text { menginap di hotel berasal dari wisatawan } \\
\text { mancanegara. }\end{array}$ & 0,1 & 3 & 0,3 \\
$\begin{array}{l}\text { 6. Adanya permintaan terhadap produk-produk } \\
\text { restoran hotel dari orang luar yang bukan } \\
\text { tamu. }\end{array}$ & 0,1 & 3 & 0,3 \\
\hline Total & 1,0 & 20 & 3,5 \\
\hline
\end{tabular}


Tabel 4. Faktor-faktor Strategis Eksternal (External Strategic Factors Analysis Summary/ EFAS) Ancaman/ Treath

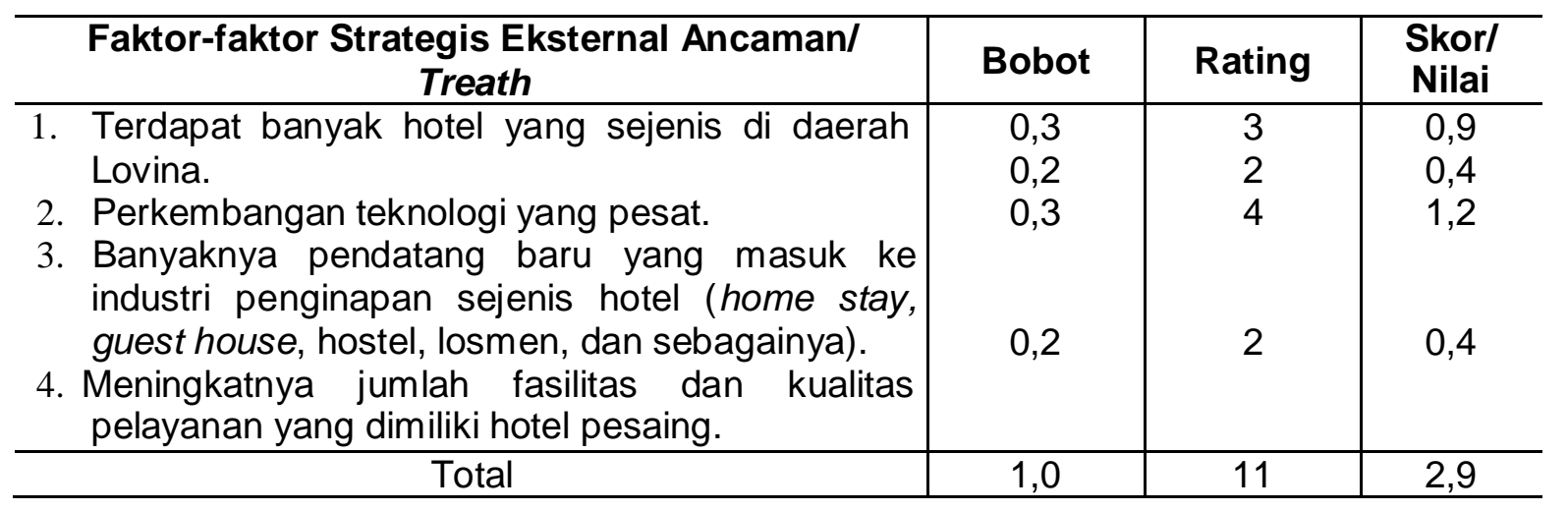

Perhitungan koordinat dari analisis internal

Sumbu X $=($ skor strength - skor treath): 2

$$
\begin{aligned}
& =(3,2-2,4): 2 \\
& =0,8: 2 \\
& =0,4
\end{aligned}
$$$$
=(3,5-2,9): 2
$$$$
=0,6: 2
$$$$
=0,3
$$

Jadi posisi perusahaan berada pada titik koordinat di $(0,4: 0,3)$

Perhitungan koordinat dari analisis eksternal

Berikutnya, hasil koordinat tersebut Sumbu $Y=$ (skor opportunities - skor treath) : 2

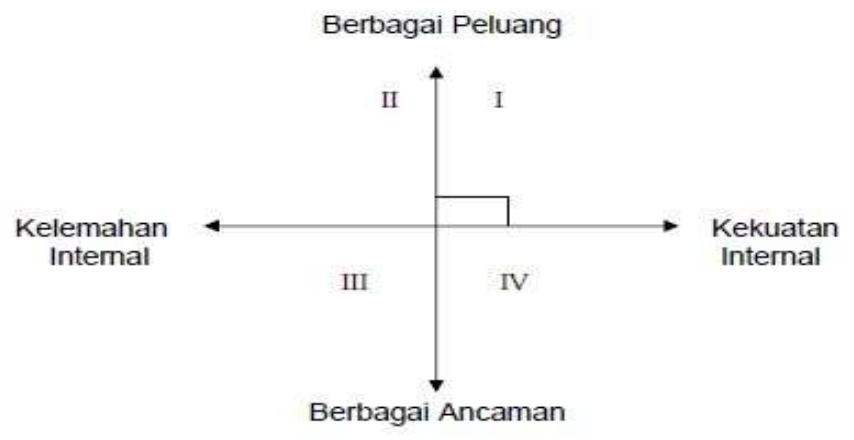
disajikan pada diagram matriks SWOT untuk mengetahui posisi perusahaan, yang akan nampak pada Gambar 1.

Gambar 1. Diagram Matriks SWOT

Setelah diketahui titik pertemuan sumbu $X$ dan sumbu $Y$, maka posisi unit usaha diketahui pada kuadran I.

Kuadran I

Pada posisi ini merupakan situasi yang sangat menguntungkan perusahaan karena perusahaan memiliki peluang dan kekuatan yang sangat besar sehingga perusahaan dapat memanfaatkan peluang yang ada. Strategi yang harus diterapkan pada kondisi ini adalah mendukung kebijaksanaan pertumbuhan yang agresif (Growth Oriented Strategy).
Kuadran II

Pada posisi ini meskipun perusahaan dihadapkan pada berbagai ancaman akan tetapi perusahaan masih memiliki kekuatan dari segi internal yang dapat mengantisipasi adanya ancaman yang timbul sewaktu-waktu. Strategi yang harus diterapkan adalah menggunakan kekuatan untuk memanfaatkan peluang jangka panjang dengan menerapkan strategi Diversifikasi Product.

Kuadran III

Pada kuadran ini perusahaan dihadapkan pada peluang pasar yang tinggi tetapi di 
lain pihak perusahaan menghadapi kendala internal yaitu kelemahan dalam perusahaan. Fokus strategi pada strategi ini adalah berusaha meminimalkan masalah-masalah internal dalam perusahaan sehingga manajemen dapat meraih dalam berbagai peluang yang ada. Strategi yang digunakan dalam strategi ini adalah mengadakan peninjauan kembali terhadap kualitas produk (Turn-Around Strategy).
Kuadran IV

Pada kondisi ini perusahaan mengalami situasi yang sangat tidak menguntungkan dimana ancaman dan kelemahan internal yang dihadapi perusahaan mengharuskan manajemen mendukung Strategy Defensif. Hasil perhitungan dari masingmasing kuadran dapat digambarkan pada Tabel

Tabel 5. Kuadran Matriks SWOT

\begin{tabular}{lllll}
\hline Kuadran & Posisi Titik & Luas Matriks & Ranking & Prioritas Strategi \\
\hline I & $(3,2: 3,5)$ & 11,2 & 1 & Growth \\
II & $(2,4: 3,5)$ & 8,4 & 3 & Stabilitas \\
III & $(2,4: 2,9)$ & 6,96 & 4 & Penciutan \\
IV & $(3,2: 2,9)$ & 9,28 & 2 & Kombinasi \\
\hline
\end{tabular}

Pada kuadran I (StrengthOpportunities Strategy), strategi umum yang dapat dilakukan oleh perusahaan adalah menggunakan kekuatan perusahaan untuk mengambil setiap peluang yang ada. Pada kuadran II (Weakness-Opportunities Strategy), perusahaan dapat membuat keunggulan pada kesempatan sebagai acuan untuk memfokuskan kegiatan dengan menghindari kelemahan. Pada kuadran III (Weakness-Treath Strategy), meminimumkan segala kelemahan untuk menghadapi setiap ancaman. Pada kuadran IV (Strength-Treath Strategy), menjadikan setiap kekuatan untuk menghadapi setiap ancaman dengan menciptakan diversifikasi untuk menciptakan peluang.

Berdasarkan matriks SWOT, didapatkan perumusan alternatif strategi yang sesuai untuk diterapkan oleh Hotel Banyualit Singaraja. Alternatif strategi tersebut diantaranya, alternatif strategi SO (Strength Opportunities) seperti mempertahankan dan meningkatkan kualitas pelayanan, mempertahankan pelanggan yang dimiliki, mempertahankan kerja sama yang baik dengan supplier, melakukan promosi, adanya penganggaran dana untuk melakukan renovasi terhadap bangunan hotel; alternatif strategi WO (Weakness Opportunities) diantaranya meningkatkan teknologi untuk meningkatkan kinerja, pengadaan fasilitas-fasilitas pendukung, pemanfaatan fasilitas dengan baik, merespon dengan cepat segala macam saran dan keluhan para tamu yang menginap; alternatif strategi ST (Strength Treath) diantaranya melakukan promosi, mengikuti perkembangan teknologi untuk meningkatkan kinerja, memperkuat citra perusahaan di mata para konsumen; alternatif strategi WT (Weakness Treath) yaitu pembaharuan fasilitas hotel, meningkatkan fasilitas-fasilitas berbasis teknologi, meningkatkan fasilitas-fasilitas pendukung demi kemudahan konsumen, pemanfaatan fasilitas dengan baik, melakukan promosi.

\section{Pembahasan}

Kekuatan (strength) yang dimiliki Hotel Banyualit Singaraja, antara lain fasilitas hotel cukup lengkap dan memadai, harga yang kompetitif, lokasi cukup strategis, kebersihan dan kenyamanan yang terjaga, karyawan yang ramah, dan adanya tempat bermain untuk anak-anak. Dalam hal ini, Hotel Banyualit Singaraja selalu berusaha menonjolkan keunggulan kompetitif yang dimiliki agar mampu bersaing dengan para pesaingnya dan selalu memberikan pelayanan yang terbaik kepada pengunjungnya. Hal tersebut sejalan dengan yang diungkapkan David (2006: 47) bahwa "kekuatan (strengths) adalah sumber daya, keterampilan, atau keunggulankeunggulan lain yang berhubungan dengan para pesaing perusahaan dan 
kebutuhan pasar yang dapat dilayani oleh perusahaan. Kekuatan tersebut merupakan kompetisi khusus yang memberikan keunggulan kompetitif bagi perusahaan".

Hasil penelitian ini juga menunjukkan bahwa kelemahan (weakness) yang dimiliki Hotel Banyualit Singaraja antara lain promosi yang belum efektif dan berkesinambungan, jumlah kamar yang sedikit kurang bisa memenuhi permintaan tamu, fasilitas gym yang belum tersedia, sistem perekrutan karyawan masih bersifat kekeluargaan, dan Hotel Banyualit Singaraja termasuk hotel tua sehingga terkadang ada keluhan dan saran dari para tamu yang menginap di sana. Dalam hal ini, hal-hal tersebut merupakan keterbatasan yang dimiliki Hotel Banyualit Singaraja yang secara efektif menghambat kinerja usaha. "Kelemahan adalah keterbatasan atau kekurangan dalam sumber daya, keterampilan, dan kapabilitas yang secara efektif menghambat kinerja perusahaan" (David, 2006: 47). Keterbatasan tersebut dapat berupa fasilitas, sumber daya keuangan, kemampuan manajemen dan keterampilan pemasaran dapat merupakan sumber dari kelemahan perusahaan.

Selain itu, hasil penelitian ini menunjukkan bahwa peluang (opportunities) yang dimiliki Hotel Banyualit Singaraja, antara lain memiliki pelanggan tetap, kerja sama yang baik dengan supplier, kondisi alam yang menjadi daya tarik para wisatawan untuk datang ke Buleleng, pendapatan per kapita wisatawan yang tinggi akan menjadi peluang wisawatan untuk melakukan perjalanan lebih lama sehingga lama menginap di hotel juga lebih panjang, pangsa pasar yang lebih dominan menginap di hotel berasal dari wisatawan mancanegara, dan adanya permintaan terhadap produk-produk restoran hotel dari orang luar yang bukan tamu. Dalam hal ini, keenam hal tersebut merupakan peluang yang dimiliki Hotel Banyualit Singaraja. Jika peluang tersebut dimanfaatkan dengan baik, akan menguntungkan perusahaan dalam hal pencapaian tujuan usaha. Hal tersebut sejalan dengan yang dikatakan David
(2006: 47) bahwa "peluang (opportunities) adalah situasi penting yang menguntungkan dalam lingkungan perusahaan, seperti perubahan teknologi dan meningkatnya hubungan antara perusahaan dengan pembeli atau pemasok".

Hasil penelitian ini juga menunjukkan bahwa ancaman (treath) yang dimiliki Hotel Banyualit Singaraja, antara lain terdapat banyak hotel yang sejenis di daerah Lovina, perkembangan teknologi yang pesat, banyaknya pendatang baru yang masuk ke industri penginapan sejenis hotel (home stay, guest house, hostel, losmen, dan sebagainya), dan meningkatnya jumlah fasilitas dan kualitas pelayanan yang dimiliki hotel pesaing. Dalam hal ini, keempat hal tersebut merupakan hal yang tidak menguntungkan bagi Hotel Banyualit Singaraja karena ancaman yang dihadapi akan menghambat atau mengganggu tercapainya tujuan usaha yang diinginkan. "Ancaman (treath) adalah situasi penting yang tidak menguntungkan dalam lingkungan perusahaan" (David, 2006: 47). Ancaman merupakan pengganggu utama bagi posisi sekarang atau yang diinginkan perusahaan.

Hasil penelitian ini juga menunjukkan bahwa $(0,4: 0,3)$. Data tersebut diperoleh melalui analisis faktor strategis internal/ IFAS, analisis faktor strategis eksternal/ EFAS, dan analisis matriks SWOT.

Sebagaimana diuraikan di atas, memperlihatkan bahwa posisi Hotel Banyualit berada pada kuadran I pada matriks SWOT. Dengan kondisi seperti ini perusahaan dihadapkan pada situasi usaha yang mulai berkembang dan disarankan untuk melakukan strategi growth oriented strategy, dimana dalam strategi ini perusahaan diharapkan agar bisa mempertahankan keadaan usaha yang sudah mulai berkembang dengan tetap menawarkan produk-produk yang bervariasi dan juga harga yang terjangkau serta meningkatkan fasilitas-fasilitas yang ditawarkan. Hasil yang diperoleh ini senada dengan pendapat Rangkuti (2006: 19) bahwa "posisi ini merupakan situasi yang sangat menguntungkan perusahaan karena perusahaan memiliki peluang dan 
kekuatan yang sangat besar sehingga perusahaan dapat memanfaatkan peluang yang ada". Strategi yang harus diterapkan pada kondisi ini adalah mendukung kebijaksanaan pertumbuhan yang agresif (growth oriented strategy).

Temuan tersebut senada dengan temuan penelitian yang dilakukan oleh Kusuma (2011). Penelitian yang berjudul "Analisis SWOT Untuk Menetapkan Formulasi dan Implementasi Strategi Perusahaan (Studi Kasus di PT. Bank Jatim Cabang Malang)" ini memberikan gambaran bahwa PT. Bank Jatim berada pada posisi kuadran I. Temuan yang sama juga tampak pada penelitian yang dilakukan oleh Permatasari (2010). Penelitian yang berjudul "Analisis Lingkungan Eksternal dan Lingkungan Internal Sebagai Dasar Penetapan Strategi (Studi Kasus Pada RSUD Dr. Iskak Tulungagung)" ini memperlihatkan bahwa posisi pelaku usaha berada pada posisi kuadran I.

\section{SIMPULAN DAN SARAN Simpulan}

Berdasarkan analisis data yang telah disajikan, maka dapat diambil simpulan bahwa kekuatan yang dimiliki Hotel Banyualit Singaraja meliputi fasilitas hotel cukup lengkap dan memadai, harga yang kompetitif, lokasi cukup strategis, kebersihan dan kenyamanan yang terjaga, karyawan yang ramah, dan adanya tempat bermain untuk anak-anak; kelemahan yang dimiliki Hotel Banyualit Singaraja meliputi promosi yang belum efektif dan berkesinambungan, jumlah kamar yang sedikit kurang bisa memenuhi permintaan tamu, fasilitas gym yang belum tersedia, sistem perekrutan karyawan masih bersifat kekeluargaan, dan Hotel Banyualit termasuk hotel tua sehingga terkadang ada keluhan dan saran dari para tamu yang menginap di sana; peluang yang dimiliki Hotel Banyualit Singaraja meliputi memiliki pelanggan tetap, kerja sama yang baik dengan supplier, kondisi alam yang menjadi daya tarik para wisatawan untuk datang ke Buleleng, pendapatan per kapita wisatawan yang tinggi akan menjadi peluang wisawatan untuk melakukan perjalanan lebih lama sehingga lama menginap di hotel juga lebih panjang, pangsa pasar yang lebih dominan menginap di hotel berasal dari wisatawan mancanegara, dan adanya permintaan terhadap produk-produk restoran hotel dari orang luar yang bukan tamu; ancaman yang dihadapi Hotel Banyualit Singaraja meliputi terdapat banyak hotel yang sejenis di daerah Lovina, perkembangan teknologi yang pesat, banyaknya pendatang baru yang masuk ke industri penginapan sejenis hotel (home stay, guest house, hostel, losmen, dan sebagainya), dan meningkatnya jumlah fasilitas dan kualitas pelayanan yang dimiliki hotel pesaing; berdasarkan kekuatan dan peluang yang dimiliki serta kelemahan dan ancaman yang ada dan dari analisis faktor strategi internal dan eksternal, diketahui posisi hotel berada pada kuadran I, maka strategi yang harus diterapkan dalam kondisi ini adalah mendukung kebijaksanaan pertumbuhan yang agresif (growth oriented strategy). Alternatif strategi yang dianjurkan adalah mempertahankan dan meningkatkan kualitas pelayanan, mempertahankan pelanggan yang dimiliki, adanya penganggaran dana untuk melakukan renovasi terhadap bangunan hotel, mempertahankan kerja sama yang baik dengan supplier, dan melakukan promosi.

\section{Saran}

Saran-saran yang dapat dikemukakan sebagai masukan yang perlu dipertimbangkan oleh Hotel Banyualit Singaraja adalah dalam kondisi hotel yang masih berkembang saat ini diharapkan Hotel Banyualit Singaraja agar tetap mempertahankan kualitas pelayanan, tetap menawarkan produk dengan harga yang kompetitif dan terjangkau dan disarankan untuk menerapkan growth oriented strategy atau strategi yang bersifat agresif (perkembangan maju); persaingan saat ini semakin ketat akibat munculnya hotelhotel baru yang sejenis, dalam menghadapi persaingan tersebut, Hotel Banyualit Singaraja hendaknya mampu mempertahankan dan meningkatkan kelebihan-kelebihan yang dimiliki untuk memperoleh peluang yang ada; untuk 
p-ISSN : 2599-1418

e-ISSN : 2599-1426

memanfaatkan fasilitas dengan baik dan menambah fasilitas pendukung lainnya yang dibutuhkan oleh para konsumen.

\section{DAFTAR PUSTAKA}

Asri, Marwan. 2001. Manajemen Keuangan. Yogyakarta: BPFE.

Daft, Richard L. 2003. Management (Fifth Edition). Jakarta: Erlangga.

David, Fred R. 2006. Manajemen Strategis: Konsep Edisi Sepuluh. Jakarta: Salemba Empat.

Durianto, Sugiarto dan Tony Sitinjak. 2001. Strategi Menaklukkan Pasar Melalui Riset Ekuitas dan Perilaku Merek. Jakarta: Gramedia.

Hitt, Michael A. 2001. Manajemen Strategis: Daya Saing dan Globalisasi Edisi Pertama. Jakarta: Salemba Empat.

Irawan, dkk. 2001. Pemasaran, Prinsip, dan Kasus Edisi Kedua. Yogyakarta: BPFE.

Kotler, Philip dan A.B Susanto. 2000. Manajemen Pemasaran di Indonesia 2 (Edisi 8). Jakarta: Salemba Empat.

Kusuma, Afrieta. 2011. Analisis SWOT untuk Menetapkan Formulasi dan Implementasi Strategi Perusahaan (Studi Kasus di PT. Bank Jatim Cabang Malang). Skripsi (tidak diterbitkan). Program Studi Sarjana Akuntansi, Universitas Brawijaya (diakses 16 Desember 2018).

Mustami, Adinda Ade. 2016. Tiga Sektor Penyumbang PDB Terbesar, Melambat. Tersedia pada: http://nasional.kontan.co.id (diakses pada tanggal 13 November 2017).

Nurcahya, Ayu. 2017. Industri Perhotelan: Pasar Indonesia yang Kian Menggoda. Tersedia pada: https://m.bisnis.com (diakses pada tanggal 13 November 2017).

Permatasari, Ditya. 2010. Analisis Lingkungan Eksternal dan
Jurnal Pendidikan Ekonomi Undiksha

Volume 10 No. 2 Tahun 2018

Lingkungan Internal Sebagai Dasar Penetapan Strategi (Studi Kasus pada RSUD Dr. Iskak Tulungagung). Skripsi (tidak diterbitkan). Program Studi Sarjana Akuntansi, Universitas Brawijaya. (diakses 16 Desember 2018).

Rangkuti, Freddy. 2006. Analisis SWOT Teknik Membedah Kasus Bisnis Cetakan Ke-16. Jakarta: Gramedia Pustaka Utama.

Sugiyono. 2001. Metode Penilaian. Bandung: Alfabeta.

Susanto, AB. 2014. Managemen Strategik Komprehensif. Jakarta: Erlangga.

Suyanto, M. 2007. Strategic Management Global Most Admired Companies. Yogyakarta: Andi Offset.

Tunggal, Amin Wijaya. 2001. Tanya Jawab Manajemen Internasional. Jakarta: Harvarindo.

Yogi, Adang Widjana, dkk. 2007. Manajemen Strategik Terapan. Jakarta: Polyama Widy Pustaka. 